\title{
Interactions of the 4-quinolones with other antibacterials
}

\author{
C. S. LEWIN* and J. T. SMITH†
}

\section{Microbiology Section, Department of Pharmaceutics, The School of Pharmacy, London University, Brunswick Square, London WC1N 1AX}

\begin{abstract}
Summary. The effect of sub-inhibitory concentrations of 16 antibacterials on the bactericidal activity of the 4-quinolones nalidixic acid, ciprofloxacin and ofloxacin against Escherichia coli KL16 in nutrient broth was investigated. Sub-inhibitory concentrations of rifampicin, clindamycin, chloramphenicol, erythromycin or tetracycline antagonised the bactericidal activity of the 4-quinolones. Conversely, all seven aminoglycosides tested enhanced the bactericidal activity of the 4-quinolones whereas the cell wall antagonists, azlocillin, mezlocillin, ceftazidime and vancomycin had no effect on the bactericidal activity of the 4-quinolones.
\end{abstract}

\section{Introduction}

MIC (minimum inhibitory concentration) studies suggest that little interaction occurs between the 4-quinolones and other antibacterials (Neu and Labthavikul, 1982; Van der Auwera, 1985; Davies and Cohen, 1985; Wolfson and Hooper, 1985; Smith et al., 1986). However, MICs provide information only about the inhibition of bacterial multiplication and provide no information on the bacterial killing process (Smith, 1984) which may be important in neutropenic patients. As protein and RNA synthesis are known to be prerequisites for the full bactericidal activity of the 4-quinolones (Dietz et al., 1966; Smith, 1984), it is not surprising that the protein synthesis inhibitor chloramphenicol and the RNA synthesis inhibitor rifampicin have been found to antagonise the bactericidal activity of the 4-quinolones (Smith, 1984) although they do not affect the bacteriostatic activity of the 4-quinolones. The effects of sub-inhibitory concentrations of 16 different antibacterials on the bactericidal activity of nalidixic acid, ciprofloxacin and ofloxacin against Escherichia coli KL16 in nutrient broth were therefore investigated.

\section{Materials and methods}

\section{Antibacterials}

The following antibacterial agents were obtained from the indicated suppliers: amikacin (Bristol Laboratories), azlocillin (Bayer), ceftazidime (Glaxo), chloramphenicol

Received 24 Aug. 1988; revised version accepted 31 Jan. 1989.

* Present address: Bacteriology Department, Medical School, Teviot Place, Edinburgh EH8 9AG.

† Correspondence should be sent to Professor J. T. Smith.
(Parke-Davis), ciprofloxacin (Bayer), clindamycin (Upjohn), erythromycin (Eli Lilly and Co.), gentamicin (Roussel Laboratories), kanamycin (Bristol Laboratories), mezlocillin (Bayer), nalidixic acid (Sterling-Winthrop), netilmicin (Schering Corporation), ofloxacin (Hoeschst), rifampicin (Merrell Dow Pharmaceuticals), sisomicin (Schering Corporation), streptomycin (Evans Meciical Ltd), tetracycline (Lederle Laboratories), tobramycin and vancomycin (Eli Lilly and Co.).

All except erythromycin, nalidixic acid, ofloxacin and rifampicin were dissolved in sterile distilled water. Rifampicin and erythromycin were dissolved in absolute alcohol or dimethyl sulphoxide. Nalidixic acid and ofloxacin were first dissolved in $0.5 \mathrm{M} \mathrm{NaOH}(0.02 \mathrm{ml} /$ $\mathrm{mg}$ ) before being diluted to appropriate concentrations in sterile distilled water.

\section{Determination of bactericidal activity}

The 4-quinolones cause filamentation of bacteria, which increases the turbidity of liquid cultures, so bacterial killing by the 4-quinolones cannot be judged by light scattering or optical density measurements (Smith, 1984). The bactericidal activity of the 4-quinolones studied was measured therefore by determining viable counts.

Nutrient Broth No. 2 (Oxoid) was inoculated with $E$. coli KL16 and incubated overnight at $37^{\circ} \mathrm{C}$.

Sterile double strength nutrient broth $(5 \mathrm{ml})$ was added to the aqueous drug (or drugs) and the volume was made up to $9.8 \mathrm{ml}$ with sterile distilled water. The antimicrobial solutions were incubated at $37^{\circ} \mathrm{C}$ for at least $15 \mathrm{~min}$ and then $0.2 \mathrm{ml}$ of an overnight culture of E. coli KL16 which contained c. $5 \times 10^{8} \mathrm{cfu} / \mathrm{ml}$ was added at time zero to complete the reaction mixtures. The viable count at time zero was c. $10^{7} \mathrm{cfu} / \mathrm{ml}$. At $30-\mathrm{min}$ intervals, $0 \cdot 1-\mathrm{ml}$ samples from each reaction mixture were taken and serial 10-fold dilution were made in sterile nutrient broth. A $0 \cdot 1-\mathrm{ml}$ sample of each dilution was plated on to nutrient 
agar and the number of colonies was counted after incubation overnight at $37^{\circ} \mathrm{C}$. The results obtained were used to calculate the $99 \%$ kill time against $E$. coli KL16 of the 4-quinolone with and without a sub-inhibitory concentration of a second antibacterial.

\section{Results}

Bacteriostatic concentrations of rifampicin or chloramphenicol reduced the bactericidal activity of ciprofloxacin and totally inhibited the bactericidal activity of nalidixic acid against $E$. coli $\mathrm{KL} 16$ in nutrient broth. When sub-inhibitory concentrations of these two drugs were combined with nalidixic acid $50 \mathrm{mg} / \mathrm{L}$ or ciprofloxacin $0.015 \mathrm{mg} / \mathrm{L}$ the time taken to kill $99 \%$ of the $E$. coli $\mathrm{KLl} 16$ in nutrient broth was greater than when the 4quinolones were used alone (tables I and II).

Table I. Interactions between nalidixic acid $50 \mathrm{mg} / \mathrm{L}$ and other antibacterials against $E$. coli KL16

\begin{tabular}{|c|c|c|c|c|}
\hline \multirow{2}{*}{$\begin{array}{l}\text { Non-quinolone antibacteri- } \\
\text { als and sub-inhibitory con- } \\
\text { centrations }(\mathrm{mg} / \mathrm{L})\end{array}$} & \multirow[b]{2}{*}{$\begin{array}{c}\mathrm{MIC} \\
(\mathrm{mg} / \mathrm{L})\end{array}$} & \multicolumn{3}{|c|}{$99 \%$ kill times $(\min )^{*}$ with nalidixic acid } \\
\hline & & $\begin{array}{l}\text { 4-quinolone } \\
\text { alone }\end{array}$ & $\begin{array}{l}\text { 4-quinolone }+ \\
\text { other drug }\end{array}$ & Change $(\%)$ \\
\hline Streptomycin (2) & 3 & 153 & 130 & -23 \\
\hline Gentamicin $(0 \cdot 2)$ & $0 \cdot 3$ & 163 & 116 & -47 \\
\hline Kanamycin $(0.8)$ & 1 & 156 & 106 & -50 \\
\hline Tobramycin $(0 \cdot 4)$ & 0.5 & 191 & 98 & -93 \\
\hline Amikacin $(0.4)$ & 0.5 & 168 & 127 & -41 \\
\hline Sisomicin $(0.4)$ & 0.5 & 127 & 72 & -55 \\
\hline Netilmicin $(0.4)$ & 0.5 & 142 & 86 & -56 \\
\hline Rifampicin (10) & 15 & 128 & 252 & +124 \\
\hline Tetracycline $(0.3)$ & 2 & 142 & 260 & +118 \\
\hline Chloramphenicol (1) & 4 & 141 & 175 & +34 \\
\hline Erythromycin (30) & 40 & 178 & $>300$ & $>+122$ \\
\hline Clindamycin (10) & 30 & 172 & $>240$ & $>+68$ \\
\hline Vancomycin $(0.4)$ & 3 & 154 & 154 & $\begin{array}{c}\mathrm{T} \\
0\end{array}$ \\
\hline Azlocillin (1) & $7 \cdot 5$ & 187 & 187 & 0 \\
\hline Mezlocillin $(0 \cdot 3)$ & 1.5 & 183 & 183 & 0 \\
\hline Ceftazidime $(0.03)$ & $0 \cdot 15$ & 201 & 201 & 0 \\
\hline
\end{tabular}

* See Methods.

Table II. Interactions between ciprofloxacin $0.015 \mathrm{mg} / \mathrm{L}$ and other antibacterials against $E$. coli KL16

\begin{tabular}{lcccc}
\hline & \multicolumn{4}{c}{$99 \%$ kill times (min) with ciprofloxacin } \\
\cline { 3 - 5 } $\begin{array}{l}\text { Non-quinolone antibacteri- } \\
\text { als and sub-inhibitory con- } \\
\text { centrations (mg/L) }\end{array}$ & $\begin{array}{c}\text { MIC } \\
(\mathrm{mg} / \mathrm{L})\end{array}$ & $\begin{array}{c}\text { 4-quinolone } \\
\text { alone }\end{array}$ & $\begin{array}{c}\text { 4-quinolone }+ \\
\text { other drug }\end{array}$ & Change (\%) \\
\hline Streptomycin (2) & 3 & 168 & 128 & -40 \\
Gentamicin (0.2) & $0 \cdot 3$ & 156 & 128 & -28 \\
Kanamycin (0.8) & 1 & 137 & 108 & -29 \\
Tobramycin (0.4) & $0 \cdot 5$ & 194 & 141 & -53 \\
Amikacin (0.4) & $0 \cdot 5$ & 117 & 106 & -11 \\
Sisomicin (0.4) & $0 \cdot 5$ & 166 & 85 & -81 \\
Netilmicin (0.4) & $0 \cdot 5$ & 160 & 99 & -61 \\
Rifampicin (10) & 15 & 143 & 146 & +3 \\
Tetracycline (0.3) & 2 & 138 & 241 & +103 \\
Chloramphenicol (1) & 4 & 128 & 193 & +65 \\
Erythromycin (30) & 40 & 180 & $>300$ & $>+120$ \\
Clindamycin (10) & 30 & 200 & $>240$ & $>+40$ \\
Vancomycin (0.4) & 3 & 154 & 154 & 0 \\
Azlocillin (1) & $7 \cdot 5$ & 185 & 185 & 0 \\
Mezlocillin (0.3) & $1 \cdot 5$ & 210 & 210 & 0 \\
Ceftazidime (0.03) & $0 \cdot 15$ & 210 & 210 & 0 \\
\hline
\end{tabular}


Sub-inhibitory concentrations of three other inhibitors of protein synthesis, tetracycline $0.03 \mathrm{mg} / \mathrm{L}$, erythromycin $30 \mathrm{mg} / \mathrm{L}$ and clindamycin $10 \mathrm{mg} / \mathrm{L}$ were also tested for their effect on the bactericidal activity of the 4-quinolones. All three antibacterials increased the $99 \%$ kill times of nalidixic acid $50 \mathrm{mg} / \mathrm{L}$ (fig. 1 and table I) and of ciprofloxacin $0.015 \mathrm{mg} / \mathrm{L}$ (fig. 1 and table II) against $E$. coli $\mathrm{KL} 16$ in nutrient broth. The bactericidal activity of the two 4-quinolones appears, therefore, to be antagonised by these inhibitors of protein synthesis at sub-inhibitory concentrations.

The aminoglycosides were similarly examined. These antimicrobials also inhibit bacterial protein synthesis and antagonism of the bactericidal activity of the 4-quinolones might have been expected. However, the bactericidal activities of nalidixic acid $50 \mathrm{mg} / \mathrm{L}$ (fig. 2 and table I) and of ciprofloxacin $0.015 \mathrm{mg} / \mathrm{L}$ (fig. 2 and table II) were enhanced by a sub-inhibitory concentration of the L-aminoglyco-
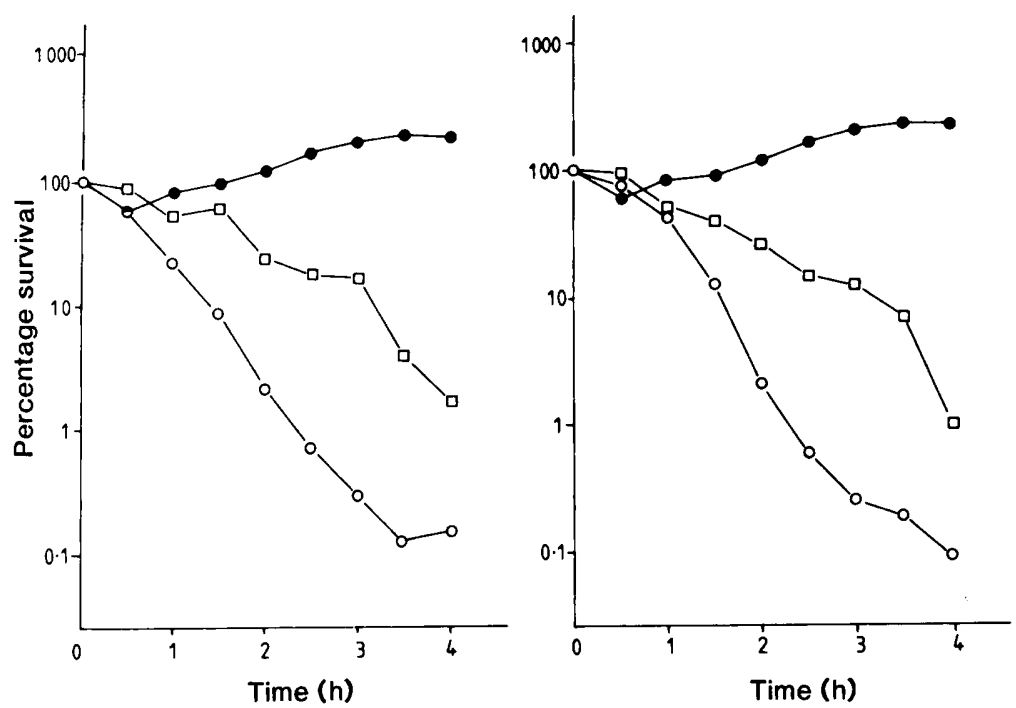

Fig. 1. Survival of E. coli KL16 in nutrient broth with antibacterials. A 1 in 50 dilution of an overnight culture was made in nutrient broth containing nalidixic acid $50 \mathrm{mg} / \mathrm{L}(\mathbf{a}, \bigcirc-O)$, ciprofloxacin $0.015 \mathrm{mg} / \mathrm{L}(\mathbf{b}, \bigcirc-\bigcirc)$, tetracycline $0.3 \mathrm{mg} / \mathrm{L}(\mathbf{a}$ and $\mathbf{b}, 0-0)$, nalidixic acid + tetracycline $(a, \square-\square)$ or ciprofloxacin + tetracycline $(\mathbf{b}, \square-\square)$. Samples were taken at 30 -min intervals and bacterial survival was estimated by viable counts on nutrient agar.
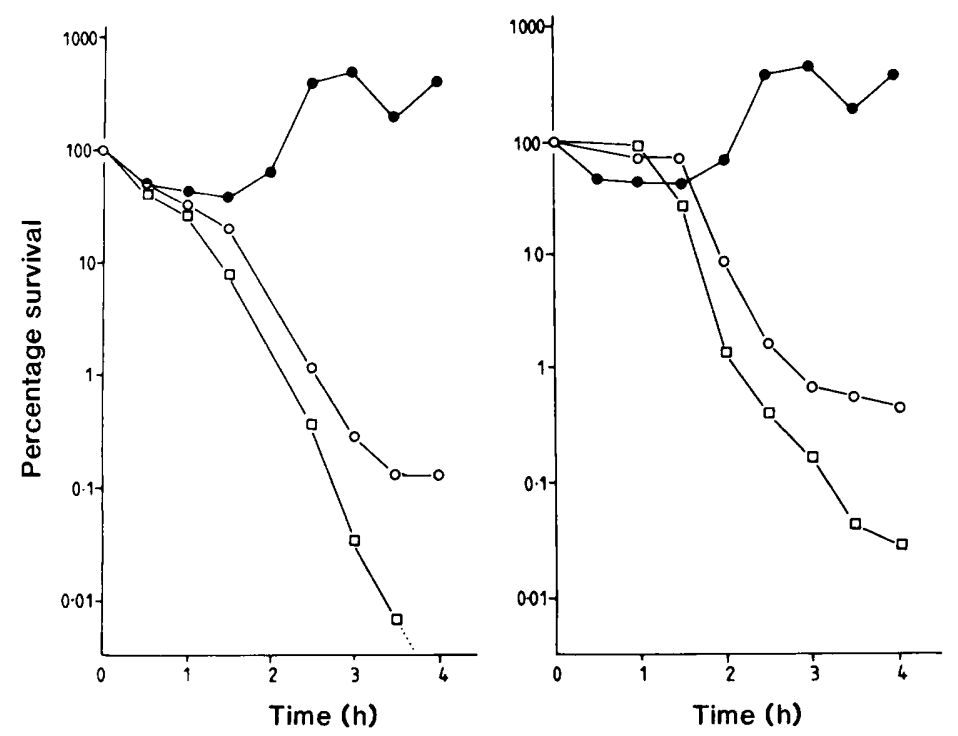

Fig. 2. Survival of $E$. coli KL16 in nutrient broth containing nalidixic acid $50 \mathrm{mg} / \mathrm{L}(\mathrm{a}, \bigcirc-\bigcirc)$, ciprofloxacin $0.015 \mathrm{mg} / \mathrm{L}$ (b, $\bigcirc-$ $\mathrm{O})$, streptomycin $2 \mathrm{mg} / \mathrm{L}$ (a and b, - - ), nalidixic acid + streptomycin (a, $\square-\square$ ) or ciprofloxacin + streptomycin (b, $\square-\square$ ). 
Table III. Interactions between ofloxacin $0.06 \mathrm{mg} / \mathrm{L}$ and other antibacterials against $E$. coli KL16

\begin{tabular}{|c|c|c|c|c|}
\hline \multirow{2}{*}{$\begin{array}{l}\text { Non-quinolone antibacteri- } \\
\text { als and sub-inhibitory } \\
\text { concentrations }(\mathrm{mg} / \mathrm{L})\end{array}$} & \multirow[b]{2}{*}{$\begin{array}{c}\mathrm{MIC} \\
(\mathrm{mg} / \mathrm{L})\end{array}$} & \multicolumn{3}{|c|}{$99 \%$ kill times $(\mathrm{min})$ with ofloxacin } \\
\hline & & $\begin{array}{l}\text { 4-quinolone } \\
\text { alone }\end{array}$ & $\begin{array}{c}\text { 4-quinolone + } \\
\text { other drug }\end{array}$ & Change $(\%)$ \\
\hline Streptomycin (2) & 3 & 161 & 133 & -28 \\
\hline Gentamicin $(0 \cdot 2)$ & $0 \cdot 3$ & 161 & 141 & -20 \\
\hline Kanamycin (0.8) & 1 & 170 & 154 & -16 \\
\hline Tobramycin $(0 \cdot 4)$ & $0 \cdot 5$ & 170 & 127 & -43 \\
\hline Amikacin $(0 \cdot 4)$ & 0.5 & 165 & 138 & -27 \\
\hline Sisomicin $(0.4)$ & $0 \cdot 5$ & 132 & 118 & -14 \\
\hline Netilmicin $(0 \cdot 4)$ & 0.5 & 165 & 121 & -44 \\
\hline Rifampicin (10) & 15 & 132 & 153 & +21 \\
\hline Tetracycline $(0 \cdot 3)$ & 2 & 133 & $>240$ & $>+107$ \\
\hline Chloramphenicol (1) & 4 & 133 & 236 & 103 \\
\hline Erythromycin (30) & 40 & 148 & $>240$ & $>+92$ \\
\hline Clindamycin (10) & 30 & 148 & 187 & +39 \\
\hline Vancomycin $(0 \cdot 4)$ & 3 & 156 & 155 & -1 \\
\hline Azlocillin (1) & $7 \cdot 5$ & 156 & 158 & +2 \\
\hline Mezlocillin $(0 \cdot 3)$ & $1 \cdot 5$ & 152 & 150 & -2 \\
\hline Ceftazidime $(0.03)$ & $0 \cdot 15$ & 152 & 150 & -2 \\
\hline
\end{tabular}

side streptomycin $(2 \mathrm{mg} / \mathrm{L})$. The effect was progressive with the bactericidal activity of nalidixic acid $50 \mathrm{mg} / \mathrm{L}$ being increasingly enhanced by streptomycin $2 \mathrm{mg} / \mathrm{L}$ over $7 \mathrm{~h}$ (fig. 3 ).

The bactericidal activities of nalidixic acid

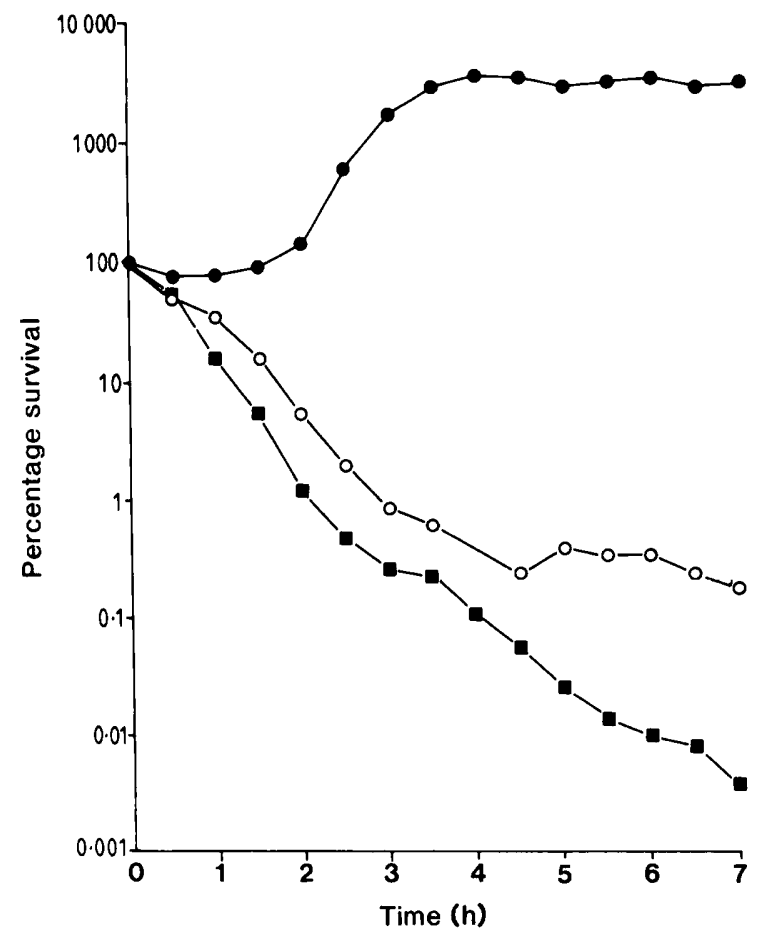

Fig. 3. Survival of $E$. coli KL16 in nutrient broth containing nalidixic acid $50 \mathrm{mg} / \mathrm{L}(\mathrm{O}-\mathrm{O})$, streptomycin $2 \mathrm{mg} / \mathrm{L}(\mathrm{O}-\mathrm{O})$ or nalidixic acid + streptomycin ( $\square-\mathrm{D})$.
$50 \mathrm{mg} / \mathrm{L}$ (fig. 4 and table I) and of ciprofloxacin $0.015 \mathrm{mg} / \mathrm{L}$ (fig. 4 and table II) were also enhanced by a sub-inhibitory concentration of the D-aminoglycoside tobramycin $(0.4 \mathrm{mg} / \mathrm{L})$. When a further five aminoglycosides were tested they also enhanced the bactericidal activity of nalidixic acid $50 \mathrm{mg} / \mathrm{L}$ (table I) and of ciprofloxacin $0.015 \mathrm{mg} / \mathrm{L}$ (table II) against $E$. coli KL16 in nutrient broth. Therefore, the aminoglycosides appear to enhance the bactericidal activity of ciprofloxacin and nalidixic acid, whereas the other protein synthesis inhibitors antagonise the 4-quinolone bactericidal activity.

A beneficial interaction often occurs between two antibacterials when the drug concentrations are sub-optimal rather than optimal. However, sisomicin $0.4 \mathrm{mg} / \mathrm{L}$ was not only able to enhance the bactericidal activity of ciprofloxacin $0.015 \mathrm{mg} /$ $\mathrm{L}$ against $E$. coli KL16 but when ciprofloxacin was used at its maximum bactericidal concentration of $0.15 \mathrm{mg} / \mathrm{L}$, potentiation still occurred (fig. 5). Hence, even the optimal bactericidal activity of the 4-quinolones was enhanced by the aminoglycosides.

The interactions of the two 4-quinolones with sub-inhibitory concentrations of inhibitors of cellwall synthesis, including vancomycin which has already been used in combination with ciprofloxacin (Smith et al., 1988), were also examined. Vancomycin at a sub-inhibitory concentration of $0.4 \mathrm{mg} / \mathrm{L}$ had no effect on the bactericidal activity of either nalidixic acid $50 \mathrm{mg} / \mathrm{L}$ or of ciprofloxacin $0.015 \mathrm{mg} / \mathrm{L}$ against $E$. coli $\mathrm{KL} 16$ in nutrient broth (fig. 6 and tables I and II). The bactericidal 

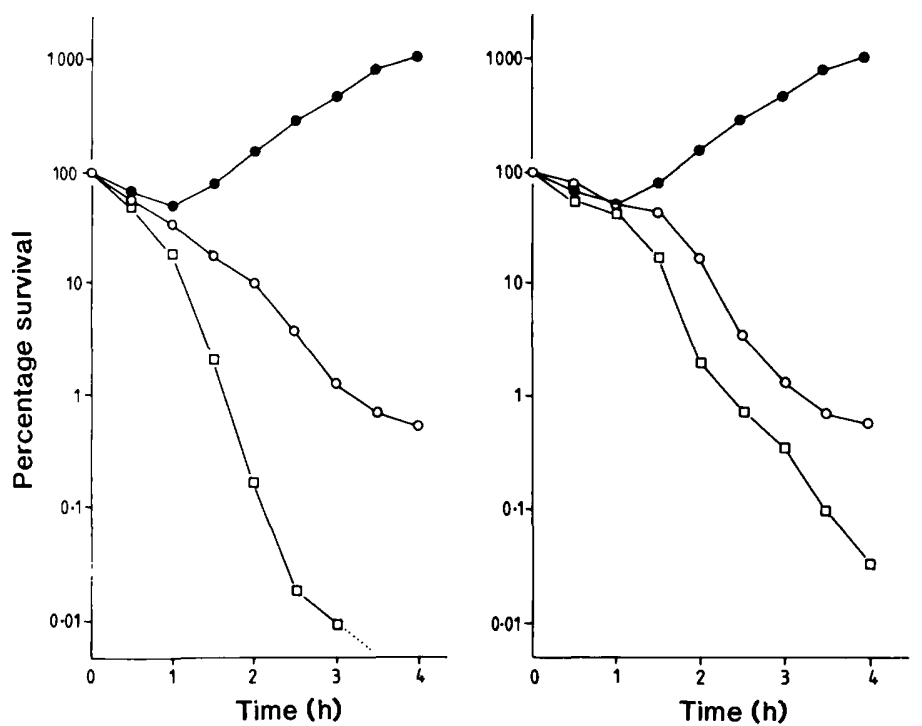

Fig. 4. Survival of $E$. coli $\mathrm{KL} 16$ in nutrient broth containing nalidixic acid $50 \mathrm{mg} / \mathrm{L} \mathrm{(a,} \bigcirc-\bigcirc)$, ciprofloxacin $0.015 \mathrm{mg} / \mathrm{L}$ (b, $\bigcirc-$ O), tobramycin $0.4 \mathrm{mg} / \mathrm{L}$ (a and b, - - ) nalidixic acid + tobramycin (a, $\square-\square$ ) or ciprofloxacin + tobramycin (b, $\square-\square$ ).
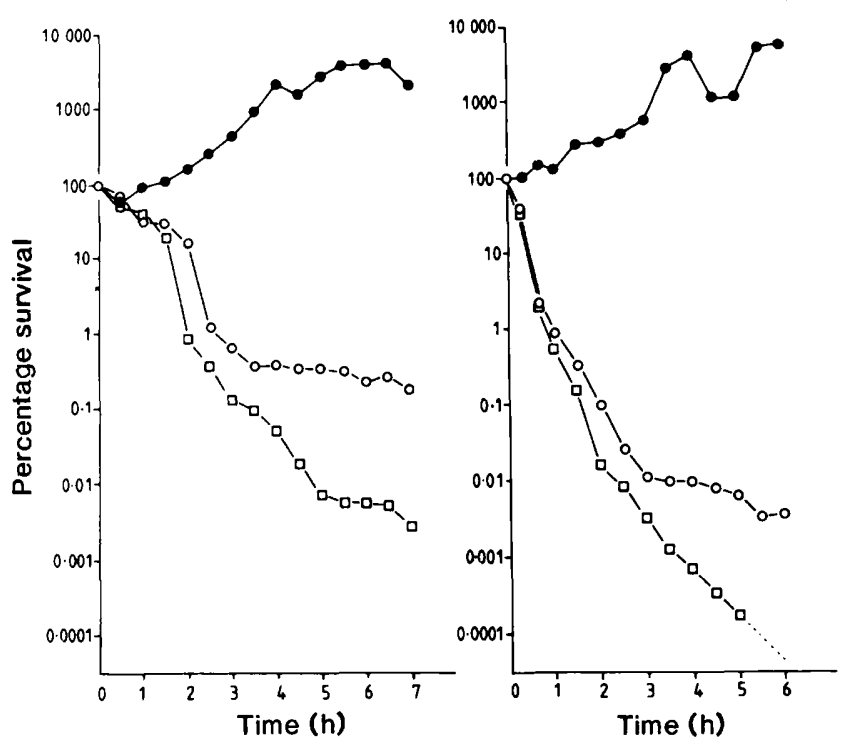

Fig. 5. Survival of $E$. coli $\mathrm{KL} 16$ in nutrient broth containing ciprofloxacin $0.015 \mathrm{mg} / \mathrm{L} \mathrm{(a,} \bigcirc-\bigcirc)$ or $0.15 \mathrm{mg} / \mathrm{L}(\mathrm{b}, \bigcirc-O)$, sisomicin $0.4 \mathrm{mg} / \mathrm{L}$ (a and b, - - ) , ciprofloxacin $0.015 \mathrm{mg} / \mathrm{L}+\operatorname{sisomicin}(\mathbf{a}$,

activities of nalidixic acid $50 \mathrm{mg} / \mathrm{L}$ or of ciprofloxacin $0.015 \mathrm{mg} / \mathrm{L}$ against $E$. coli KL16 in nutrient broth were also found to be unaffected by subinhibitory concentrations of the $\beta$-lactam cell-wall antagonists, ceftazidime, azlocillin and mezlocillin (tables I and II). Therefore, the bactericidal activity of the two 4-quinolones against $E$. coli KLl6 appeared to be unaffected by sub-inhibitory concentrations of $\beta$-lactams or vancomycin.

The effects of sub-inhibitory concentrations of the same 16 antibacterials were also tested on a third 4-quinolone, ofloxacin. Sub-inhibitory concentrations of all seven aminoglycosides tested enhanced the bactericidal activity of ofloxacin $0.06 \mathrm{mg} / \mathrm{L}$ against $E$. coli $\mathrm{KL} 16$ in nutrient broth (table III); all the 99\% kill times were reduced. Conversely, sub-inhibitory concentrations of the other inhibitors of protein and RNA synthesis tested (rifampicin, tetracycline, chloramphenicol, erythromycin and clindamycin) increased the time required by ofloxacin $0.06 \mathrm{mg} / \mathrm{L}$ to kill $99 \%$ of the $E$. coli (table II) and hence antagonise the bacteri- 

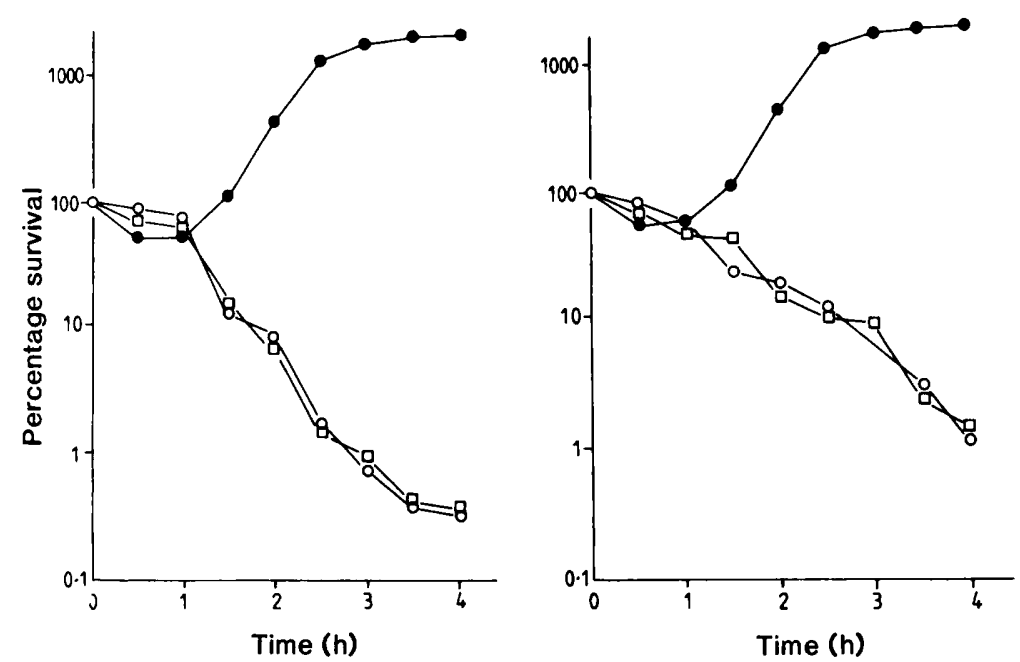

Fig. 6. Survival of $E$. coli $\mathrm{KL} 16$ in nutrient broth containing nalidixic acid $50 \mathrm{mg} / \mathrm{L}(\mathrm{a}, \mathrm{O}-\mathrm{O})$, ciprofloxacin $0.015 \mathrm{mg} / \mathrm{L}(\mathrm{b}, \mathrm{O}-$ O), vancomycin $0.4 \mathrm{mg} / \mathrm{L}$ (a and b, - - ), nalidixic acid + vancomycin (a, $\square-\square$ ) or ciprofloxacin + vancomycin (b, $\square-\square$ ).

cidal activity of the 4-quinolone. As with ciprofloxacin and nalidixic acid, the four cell-wall antagonists tested had no effect on the bactericidal activity of ofloxacin against $E$. coli KL16 in nutrient broth. The results obtained with ofloxacin were, therefore, similar to those obtained with ciprofloxacin and nalidixic acid.

\section{Discussion}

The 16 antibacterials that were investigated for their effect on the bactericidal activities of ciprofloxacin, nalidixic acid and ofloxacin against $E$. coli KL16 in nutrient broth can be divided into three groups: firstly, the RNA synthesis inhibitor rifampicin and the protein synthesis inhibitors, tetracycline, erythromycin, clindamycin and chloramphenicol, that antagonised the bactericidal activity of the 4-quinolones; secondly, the aminoglycosides that enhanced 4-quinolone bactericidal activity; and thirdly the cell-wall antagonists that had no effect on 4-quinolone bactericidal activity. The aminoglycosides also enhanced the optimal bactericidal activity of the 4-quinolones. This is not always the case with combinations of antimicrobials, as enhancement may only occur at suboptimal drug concentrations, e.g., combinations of trimethoprim and sulphonamide (Amyes, 1982).

Unlike the other inhibitors of protein and RNA synthesis tested, the aminoglycosides damage the bacterial membrane (Tanaka, 1982; Davis, 1987). This is a secondary effect related to inhibition of protein synthesis, the addition of chloramphenicol having been shown to eliminate the membrane damage caused by streptomycin (Tanaka, 1982;
Tai and Davis, 1985). It has been suggested that this damage caused to the bacterial membrane by the aminoglycosides offers an explanation for these drugs being bactericidal against $E$. coli in contrast to chloramphenicol, tetracycline and erythromycin which are merely bacteriostatic (Tanaka, 1982; Tanaka et al., 1984). The interaction between the aminoglycosides and the bacterial membrane would also seem to provide a possible explanation for the aminoglycosides forming a distinct sub-group amongst the inhibitors of protein synthesis in their interaction with the 4-quinolones. The membrane damage caused by the aminoglycosides, which is thought to be due to the incorporation of misread proteins into the membrane, increases the permeability of the membrane (Davis et al., 1986; Davis, 1987) and also interferes with the initiation step of DNA synthesis (Tanaka et al., 1984), probably by interfering with the formation of the oriC-membrane complex (Matsunaga et al., 1986). These changes in membrane permeability may increase 4-quinolone uptake. Alternatively, the aminoglycosides may act via their effect on the initiation of DNA replication because the 4-quinolones also affect the replication of DNA. The observation that sub-inhibitory concentrations of aminoglycosides enhance the killing activity of the 4-quinolones, but not vice versa (Lewin, 1987), suggests that the first hypothesis is more probable. However, further investigation is necessary to identify the mechanism by which the aminoglycosides enhance 4-quinolone bactericidal activity.

Other workers have also demonstrated synergy between aminoglycosides and ciprofloxacin in vitro (Chalkley and Koornhof, 1985). It is interesting to 
note that combinations of some cell wall antagonists and ciprofloxacin have been found to be synergic against $P_{\text {seudomonas aeruginosa in vivo as well as in }}$ vitro (Chalkley and Koornhof, 1985; Giamarellou and Petrikkos, 1987; Fu et al., 1987; Bustamente et al., 1987). Hence it is possible that the cell wall antagonists may, in some cases, act synergically with the 4-quinolones rather than the combination being additive or indifferent. However, no antagonism of the bactericidal activity of the 4-quinolones by the cell wall antagonists has been reported.

\section{REFERENCES}

Amyes, S G B 1982 Bactericidal activity of trimethoprim alone and in combination with sulfamethoxazole in susceptible and resistant Escherichia coli K12. Antimicrobial Agents and Chemotherapy 21 : 288-293.

Bustamente C I, Drusano G L, Wharton R C, Wade J C 1987 Synergism of the combinations of imipenem plus ciprofloxacin and imipenem plus amikacin against Pseudomonas aeruginosa and other bacterial pathogens. Antimicrobial Agents and Chemotherapy 31: 632-634.

Chalkley L J, Koornhof H J 1985 Antimicrobial activity of ciprofloxacin against Pseudomonas aeruginosa, Escherichia coli and Staphylococcus aureus determined by the killing curve method: antibiotic comparisons and synergistic interactions. Antimicrobial Agents and Chemotherapy 28: 331-342.

Davies G S R, Cohen J 1985 In vitro study of the activity of ciprofloxacin alone and in combination against strains of Pseudomonas aeruginosa with multiple antibiotic resistance. Journal of Antimicrobial Chemotherapy 16: 713-717.

Davis B D, Chen L, Tai P C 1986 Misread protein creates membrane channels: an essential step in the bactericidal action of aminoglycosides. Proceedings of the National Academy of Sciences of the USA 83: 6164-6168.

Davis B D 1987 Mechanism of bactericidal action of aminoglycosides. Microbiological Reviews 51 : 341-350.

Dietz W H, Cook T M, Goss W A 1966 Mechanism of action of nalidixic acid on Escherichia coli. III. Conditions required for lethality. Journal of Bacteriology 91 : 768-773.

Fu, K P, Hetzel N, Gregory F J, Hung P P 1987 Therapeutic efficacy of cefpiramide-ciprofloxacin combinations in experimental Pseudomonas infections in neutropenic mice. Journal of Antimicrobial Chemotherapy 20: 541-546.

Giamarellou H, Petrikkos G 1987 Ciprofloxacin interaction with imipenem and amikacin against multiresistant Pseudomonas aeruginosa. Antimicrobial Agents and Chemotherapy 31 : 959-961.

Lewin C S 1987 Interactions of 4-quinolone antibacterials and antibiotics with gram negative and positive bacteria. $\mathrm{Ph} . \mathrm{D}$. thesis, University of London.
In conclusion, investigations on the effect of subinhibitory concentrations of other antibacterials on the bactericidal activity of nalidixic acid, ciprofloxacin and ofloxacin against $E$. coli KL16 in nutrient broth showed no antagonism between the 4quinolones and cell wall antagonists. The aminoglycosides were found to form a distinct subgroup amongst the inhibitors of protein or RNA synthesis tested as the former enhanced the bactericidal activity of the 4-quinolones whilst the latter antagonised their bactericidal activity.

Matsunaga K, Yamaki H, Nishimuro T, Tanaka N 1986 Inhibition of DNA replication initiation by aminoglycoside antibiotics. Antimicrobial Agents and Chemotherapy 30: 468474.

Neu H C, Labthavikul P 1982 In vitro activity of norfloxacin, a quinolone-carboxylic acid, compared with that of $\beta$-lactams, aminoglycosides and trimethoprim. Antimicrobial Agents and Chemotherapy 22 : 23-27.

Smith G M, Leyland M J, Farrell I D, Geddes A M 1988 A clinical microbiological and pharmacokinetic study of ciprofloxacin plus vancomycin as initial therapy of febrile episodes in neutropenic patients. Journal of Antimicrobial Chemotherapy 21 : 647-655.

Smith J T 1984 Awakening the slumbering potential of the 4quinolone antibacterials. Pharmaceutical Journal 233: 299 305.

Smith S M, Eng R H K, Berman E 1986 The effect of ciprofloxacin on methicillin-resistant Staphylococcus aureus. Journal of Antimicrobial Chemotherapy 17: 287-295.

Tai P C, Davis B D 1985 The actions of antibiotics on the ribosome. In: Greenwood D, O'Grady F (eds) The scientific basis of antimicrobial chemotherapy. Cambridge University Press, Cambridge, pp 45-69.

Tanaka N 1982 Mechanism of action of the aminoglycoside antibiotics. In: Umezawa H, Hooper I R (eds) Aminoglycoside antibiotics; Handbook of experimental pharmacology, vol 62. Springer-Verlag, Berlin, Heidelberg, New York, pp 221-226.

Tanaka N, Matsunaga K, Yamaki H, Nishimura T K 1984 Inhibition of initiation of DNA synthesis by aminoglycoside antibiotics. Biochemical and Biophysical Research Communications 122: 460-465.

Van der Auwera P 1985 Interaction of gentamicin, dibekacin, netilmicin and amikacin with various penicillins, cephalosporins, minocycline and new fluoro-quinolones against Enterobacteriaceae and Pseudomonas aeruginosa. Journal of Antimicrobial Chemotherapy 16: 581-587.

Wolfson J S, Hooper D C 1985 The fluoroquinolones: Structures, mechanisms of action and resistance and spectra of activity in vitro. Antimicrobial Agents and Chemotherapy 28: 581586. 